\title{
El Taki Onqoy y la sociedad andina (Huamanga, siglo XVI) Steve Stern
}

\section{\}} n este artículo se examina la respuesta de los pueblos andinos frente a una grave crisis producida en las primeras décadas de la dominación colonial española. Forma parte del tercer capítulo de un estudio mayor sobre las luchas de las sociedades andinas de Huamanga y su impacto sobre el orden colonial en su conjunto, desde el inicio de la conquista española hasta 1640. En el segundo capítulo del estudio se analizan las múltiples formas de alianza y colaboración establecidas entre españoles c indígenas durante los primeros anos coloniales de Huamanga, la contraposición de intereses que desde un comienzo hizo que tal alianza fuese precaria s contradictoria, y la presencia cada vez mayor de inquietudes entre los indios respecto a las consecuencias perjudiciales e inesperadas de la colaboración andino-española. Estas inquietudes culminaron en una gran crisis andina en la década de 1560, cuando los colonizadores pretendieron reclutar grandes contingentes de mano de obra para la explotación de las nuevas minas de azogue, oro y plata de Huamanga. Surge entonces el movimiento Taki Ongoy como un esfuerzo de los pueblos andinos de Huamanga por superar la crisis de espíritu generada por las contradicciones coloniales. Entre sus postulados se encontraban, además, la supresión de relaciones y tendencias "colaboracionistas", el reordenamiento de las relaciones en el interior del mundo andino, y el tránsito hacia un nuevo orden social. En otras palabras, para los pueblos andinos de Huamanga, el Taki Ongoy fue su sueño de liberación.

\section{SU DESCUBRIMIENTO}

Li1 1564, el cura español Luis de Olivera descubre que los indios de su parroquia en Parinacochas eran participes de una herejía de características subversivils. Esta ura propagada à través de los taquiongos o mensajeros de las divinidades nativas andinas, quienes predicaban que, dentro de breve tiempo,

Traducción de Olga Mcjía. 
una alianza panandina de divinidades derrotaría al dios principal de los cristianos y exterminaría a los colonizadores españoles infligiéndoles males incurables y otras calamidades. Quienes entre los indigenas deseasen evitar un destino semejante e ingresar en una era nueva y purificada, de salud y abundancia, habrian de dedicarse al culto de las huacas vengadoras y rechazar todo tipo de colaboración con los europeos. Alarmado por los efectos de este movimiento nativista entre todos los sectores de la población indígena, Olivera llevó su descubrimiento ante las autoridades eclesiásticas de Limá Cusco y Charcas. Tiempo después y en virtud de una minuciosa inspección a cargo del clérigo Cristóbal de Albornoz, se llegaría a descubrir que la secta del Taki Ongoy contaba con miles de adherentes activos en las zonas de Lucanas, Soras, Chocorvos y Río Pampas, en Huamanga. Su influencia parecíz haberse extendido rápidamente por el norte hacia Jauja y Lima, y por el este hacia Cusco y Charcas. Este resurgimiento mesiánico vio mermada su fuerza sólo después de la vasta campaña de extirpación de idolatrías emprendida por Albornoz, que duró entre dos y tres años y durante la cual fueron condenados más de 8,000 indios ${ }^{1}$.

Apenas veinte años después de fundada Huamanga, una aguda crisis moral apareció y se extendió rápidamente dentro de la sociedad nativa, dando origen al anhelo de una nueva era postincaica, exenta de elementos hispánicos. El surgimiento del Taki Ongoy ocurrió atrededor de 1560, como expresión de un sentimiento generalizado de desconfianza y desengaño que signó todo aquel período crítico. Los nativos asignaban a sus dioses un rol decisivo en los grandes cataclismos; de ahí que su temor a los desastres que su continua colaboración con los europeos podría acarreàrles, revistiera necesariamente un carácter religioso. Los indios tuvieron entonces que revalorar sus relaciones tanto con las huacas andinas como con las divinidades católicas. La inspección antfidolatrías que "reformó" Huamanga hacia 1570, nos legó una información considerable sobre la ideología y actividades del movimiento, su composición social y liderazgo, y su capacidad para hacer frente a presiones contrarias ${ }^{2}$. A la luz del significado de símbolos y expresiones religiosas en la sociedad andina nativa, y de una comprensión histórica de las primeras relaciones coloniales en Huamanga, dicha información nos permite apreciar la convulsión que en aquel entonces llegó a dislocar la sociedad nativa.

\section{UN CONTAGIO RELIGIOSO}

De pronto y sin que indicio alguno lo advirtiera, la excitación sacudió a los indios de su postración o resignación a continuar por rumbos inexorables. 
Las huacas andinas, dejando atrás rocas, aguas o cerros, se volcaron sobre ellos, tomándolos literalmente "en posesión"; al penetrar en sus cuerpos, los "poseidos" temblaban, se sacudían, se derrumbaban y bailaban alocadamente ${ }^{3}$. El significado literal de Taki Ongoy es "mal del baile", gran parte de su ritual consistía en un canto y baile aparentemente incontrolables de los poseídos por el "mal". El acceso servía para purificar espiritualmente al poseído, quien renunciaba entonces al cristianismo para convertirse en vocero de los dioses nativos reivindicados. Las huacas podían tomar posesión de cualquiera, hasta de los niños. Un español declaraba haber visto "seis o siete muchachos e muchachas yndios. . . que andaban como tontos y gente como perdido el juicio". La inminencia de una revolución depuradora dio origen a una suerte de fiebre contagiosa. En trance de poseídos, los mensajeros de los dioses o taquiongos exhortaban a sus paisanos, "con gran calor de suerte que los que los oyan les daban crédito y tenyan por cierto que les dezian verdad en todo lo que les predicaban. .."4

Los taquiongos prometían a sus seguidores un levantamiento milenario que acabaría con el curso erróneo del pasado. Una alianza panandina de dioses nativos, organizados en dos grandes ejércitos, combatitiría al Dios de los cristianos. La victoria de Pizarro en Cajamarca, en 1532, reflejaba los resultados de una lucha cósmica mayor en la cual el Dios de los cristianos condujo a los españoles a la victoria derrotando a las huacas y al pueblo andino. Pero esta vez las huacas andinas trasiocarían los resultados: ". . . todas las guacas. . . quantas avian quemado los cristianos e destruido avian rresucitado. . . Estas se avian juntado para dar batalla a Dios. . . al qual trayan ya de vencida". Las huacas resurrectas aniquilarían también a los colonizadores españoles: ". . . los españoles desta tierra se acabarian presto por que las guacas les ordenarian enfermedades a todos para matarlos. ..". El triunfo anunciaría una nueva era purificada de todo vestigio hispánico: “. . . ahora, daba la vuelta el mundo; y que Dios y los españoles quedaban vencidos de esta vez, y todos los españoles muertos, y las ciudades de ellos anegadas" por las aguas devastadoras de un océano desbordante. La inundación habría de producirse "porque de ellos [los españoles] no hubiese memoria". A partir del cataclismo surgiría la regeneración. Las huàcas reivindicadas crearían un "nuebo mundo" habitado por "otras gentes". El nacimiento de este nuevo mundo daría origen a un paraíso andino - libre de colonizadores, pleno de bienes materiales y donde no existirían las enfermedades. Significativamente, los principales dioses de los Incas, que aún representaban una amenaza potencial a la independencia étnica, no iban destinados a desempeñar un rol de liderazgo en los ejércitos de dioses andinos ${ }^{5}$.

El resultado final que predecían los taquiongos era el paraíso para quie- 
nes permanecieran leales a las huacas y sus mensajeros, y una cruel venganza para los traidores. Las huacas "andaban por el aire, secas y muertas de hambre; porque los indios no le sacrificaban ya, ni derramaban chicha". Enfurecidas por el abandono de que habían sido objeto, las huacas destruirían a los indios desleales junto con los españoles: "habían sembrado muchas chacras de gusanus, para plantarlos en los corazones de los españoles, ganados de Castilla y los caballos, y también en los corazones de los indios que permanecen en el Cristianismo"6. Para evitar represalias, los nativos habrían ue desoír el llamado de los sacerdotes católicos y rechazar la religión, los nombres, la alimentación y la vestimenta españoles. Los taquiongos pedían a sus seguidores abstenerse de todo contacto y cooperación con la sociedad europea. Los nativos no debían ingresar en las iglesias ni servir a los curas. Debíun asimismo abandonar los tributos y rechazar la conscripción de mano de obra ${ }^{7}$. Unicamente si se plegaban a las huacas rebeldes y a sus portavoces podrían disfrutar de beneficios materiales tales como salud, paz y prosperidau, luego de la anunciada insurgencia: ". . . adorando las dichas guacas y haziendo las cerimonyas que los dichos ynventores y maestros $\left[\ell^{\circ+} \rightarrow !^{\circ} \int a\right]$ . les uezian que hiziesen les yria bien en todos sus negocios y [tendrían] salud ellos a sus hijos y sus sementeras se darian bien. ..". Quienes fuesen desleales, de otro lado. "se moririan y andarian las cabecas por el suelos y los pies arriba $y$ otros se tornarian guanacos venados y vicuñas y otros “illymales" 8 .

Los indios dieron credibilidad a los primitivos taquiongos. En Parinacochas, "los ponían [a los taquiongos] en unos cercados y allí yvan los yndios a adorarlos por tal guaca e ydolo que dezia que se le avia metido en el cuerpo"9. Bajo su supervisión, sus seguidores practicaban ritos, confesiones $y$ ayunos tendientes a ganar nuevamente el favor de las huacas. Aparte de todas las llamas, vestidos, plata, maíz, cerveza y demás ofrendas recibidas, estas reuniones les servían de foro autorizado para predicar la ideología de la secta, gestándose importantes fuerzas de oposición antihispánica ${ }^{10}$. Su prestigio fue en constante aumento y los taquiongos terminaron por convertirse en los guardianes morales de la comunidad: "Y de cuando en cuando los tales hacían sermones al pueblo, ... amenazando a los indios si del todo no dejaban el cristianismo; y reñían al cacique o indio que se llamaba nombre de cristiano. . y trajese camisa o sombrero, alpargatas u otro cualquier traje de España. .."11.

Los españoles observaban aterrorizados la capacidad de los taquiongos para demandar el respeto y la participación de cualquier persona. Hombres y mujeres, jóvenes y viejos, kurakas y campesinos, indios del ayllu o hispanizauios yanaconas - todos parecían ser vulnerables a su mensaje o abierta- 
mente eran víctimas de "accesos de posesión". Más de la mitad de los taquiongos eran mujeres ${ }^{12}$. En una zona cuya población total no sobrepasaba los 150 mil habitantes, las autoridades españolas sostuvieron haber detectado a 8,000 participantes activos ${ }^{13}$. El secretario de la campaña antiidolatrías se quejaba de que lo peor era que "todos lo creian e guardavan lo que [los taquiongos] dezian ansi caciques como yndios y biejos como los muchachos e muchachas"14. Los observadores temían que esta suerte de contagio se propalase irresistiblemente por toda la sierra andina ${ }^{15}$. Para los europeos resultó nefasto que esta herejía barriera con los logros y patrones de.cooperación anteriores. Nativos supuestamente cristianizados hicieron suya la idolatría ${ }^{16}$. Grupos y comunidades étnicas de comprobada cooperación, se trasformaron en focos de descontento, hostilidad y resistencia pasiva. Grupos nativos estratégicos estaban bajo sospecha. En las encomiendas rurales, la élite nativa, en tanto era de tendencia hispanizante y colaboracionista, jugaba un rol indispensable como mediadora entre los indios del ayllu y la élite europea. En ese sentido, la participación o el consentimiento de los kurakas tornó al movimiento Taki Ongoy en una herejía extremadamente peligrosa, "la mas dañosa que a avido desde que esta tierra se conquisto" $"$. Para la sociedad colonial en su conjunto, el fortalecimiento de un sector de indios e yanaconas de orientación hispanizante era clave para preservar el dominio europeo. Y la lealtad que los yanaconas demostraron a los patrones y sociedad europeos, infló el número de verdaderos colonizadores. Pero, bajo las nuevas condiciones, aun los indios y yanaconas de la ciudad renovaban sus lealtades andinas, y hubo algunos que incluso llegaron a destacar como dirigentes del movimiento. Albornoz se quejaba amargamente que indios aculturados, "criados entre nosotros", viajaban por distintos lugares de la sierra "rogando y exhortando a todos los que eran fieles a su señor" a creer en el advenimiento del cataclismo 18.

\section{SIGNIFICADO DEL MENSAJE DEL TAKI ONGOY}

Si bien la sociedad nativa pasó a incrementar las filas de los taquiongos, cabe preguntarse por qué los "poseídos" o "dementes"que predicaban sobre el cataclismo ganaron credibilidad en tanto mensajeros escogidos de las huacas, o por qué no fueron ignorados, objeto de burlas o tildados de simples lunáticos.

Los taquiongos se expresaban en un idioma que correspondía a la lógica y la visión del mundo populares. La creencia de que una convulsión próxima generaría -o restablecería - un "nuevo" mundo exento de desequili- 
brios, desórdenes y males del pasado, se sustentaba en una visión cíclica de la historia compartida por toda la gente del Ande ${ }^{19}$. La creencia de que una enfermedad es reflejo de la ira de las huacas o de un intercambio social malintencionado, forma parte de una visión ancestral sobre las causas de la desgracia $^{20}$. El pronóstico del futuro era una práctica generalizada en los Andes, y la gente de Lucanas y Soras - cuyo rol como agitadores del Taki Ongov era importante - tenían reputación de ser buenos adivinos ${ }^{21}$. La posesión del espíritu tampoco era algo extraño dentro de la lógica andina. Aun cuando las huacas generalmente revestian formas corporales de objetos que ahora denominaríamos "inanimados" (el agua, los cerros o las rocas), la separación entre naturaleza y humanidad no.era tan rígida en el pensamiento andino como lo es en la visión del mundo creada por las revoluciones capitalistas de la sociedad occidental. En ese contexto, para decir su mensaje las huacas aparecían antes en los sueños o en las mentes de los voceros elegidos. Poseían además una movilidad geográfica que se traducia en el hecho de poder ser preservadas como reliquias en diferentes lugares al mismo tiempo ${ }^{22}$. Li consistencia del Taki Ongoy con el habla explicativa aceptada le otorgaba una cierta plausibilidad intelectual, lo cual evitaba que la secta fuese rechazada de inınediato por considerar que su lógica interna era ridícula o ininteligible. Su grado de credibilidad intelectual no explica sin embargo por qué un movimiento llega a ganar credibilidad a nivel social. Cabe entonces preguntarse por qué los nativos optaron por considerar, en esta instancia particular, que los taquiongos no eran unos pobres tontos engañados, sino que, por el contrario, se trataba de los voceros elegidos por las revigorizadas huacas andinas que pronto enviarian un cataclismo.

El gran atractivo de los taquiongos provenía de su habilidad para unificar $y$ articular percepciones e impulsos que comenzaban a cristalizarse en la toma de conciencia de sus paisanos los acontecimientos suscitados en los años de 1560 crearon una coyuntura crítica por la desilusión, la resistencia y el cuestionamiento que aparecicron en sociedades nativas antes caracterizadas por su colaboración. La participación de las sociedades locales en las alianzas postincaicas (la colaboración andino-española antiincaica) se explica en tanto manera de preservar objetivos y normas de tradición andina la autonomía comunal o étnica, la autosuficiencia económica y la riqueza, márgenes favorables en los conflictos locales entre ayllus y comunidades, "equilibrio" en el intercambio entre seres humanos y sobrenaturales relacionadus con la comunidad. A pesar de haberse adaptado bastante bien a las condiciones existentes después de la conquista, durante los años de 1560 la gente de lluamanga vio, en definitiva, que dicho tipo de alianzas resultaban insostenibles por mucho tiempo. Los europeos con visión de encomenderos, 
inexorablemente, buscaban convertir a sus diversos aliados y clientes étnicos en una simple casta de "indios" organizados para la extracción colonial. Las huacas, a través de los taquiongos, estaban conformando la veracidad de los grandes temores que albergaban los nativos, señalando con claridad las implicancias de aquello que temían y haciendo brotar deseos ocultos de sabotaje a las relaciones coloniales y purga a la sociedad nativa de su influencia. Era cierto que el conflicto de intereses entre la sociedad hispano-católica y la sociedad andino-pagana era implacable y desbordaba las premisas establecidas originariamente para la colaboración. Era cierto que mientras lọs nativos no modificasen su actitud pacificadora hacia los europeos, no habrían sino contribuir a su propia destrucción. Además, para poderse liberar del colonialismo, la sociedad nativa tendría que pasar primero por un proceso de purificación de todo elemento hispanizante que sirviera de vínculo material o mental con los opresores. El Taki Ongoy era la expresión de una dolorosa verdad que despertaba en las sociedades locales: el conflicto entre los elementos andinos y los elementos europeos de la sociedad colonial era ineludible, irreconciliable y decisivo al mismo tiempo.

La gran verdad del Taki Ongoy -el conflicto entre nativos y blancosse sintetizaba en dos principios morales: la resistencia al mundo hispánico y la solidaridad en el interior del mundo andino. Como se verá posteriormente, no fue fácil poner en práctica cada uno de estos principios, puesto que a los nativos se les estaba exigiendo superar auténticas adaptaciones, tradiciones y ambivalencias que aún impregnaban su comportamiento hacia los europeos y entre ellos mismos. Debido precisamente a que el Taki Ongoy demándaba patrones de conducta nuevos y distintos es que tuvo que hacer frente a una crisis moral.

El primer principio, la resistencia, significaba que la sociedad andina debía despojarse de toda fórmula de adaptación conseguida anteriormente. La estrategia de "apertura" asumida por los nativos hacia los españoles y sus dioses había facilitado el colonialismo. Bajo las nuevas circunstancias, éstos debían evitar todo contacto, intercambio o servicio con dichas instituciones coloniales. Toda actitud de "apertura" debía modificarse, aun cuando el intercambio con quienes detentaban el poder en la sociedad colonial representase determinados beneficios o medios para evitar represalias. Sólo reformándose de tales hábitos, evitarían los nativos ser partícipes de su propia destrucción y disfrutar en cambio de los frutos que el anunciado cataclismo portaría.

Tal cambio de estrategiá oçàsionó, sin embargo, un grave dilema moral en el caso de las relaciones con los dioses europeos atacados por las huacas andinas. Tanto el panteón de dioses cristianos (Dios, Jesús, los santos y de- 
más figuras veneradas), como las huacas andinas, tenían incidencia directa sobre el bienestar material cotidiano. La victoria de los españoles en Cajamarca era una demostración de que los dioses cristianos eran más poderosos que las principales divinidades andinas incorporadas al Estado incaico. Nadie que estuviera en su sano juicio podía ignorar la trascendencia de tales hechos. Al igual que en otras sociedades campesinas, la autoridad de dioses y jerarcas andinos tenía una base parcial de carácter pragmático. Su éxito estaba determinado por el impacto ejercido sobre el curso de la vida material, lo cuales le permitía mantener su prestigio y autoridad ${ }^{23}$. La conquista española puso en tela de juicio el poderío de los dioses andinos, y "comprobaba" de otro lado el riesgo que acarreaba ofender a las divinidades cristianas. Fue así como la gente de Huamanga decidió optar por una estrategia andina tradicional. En vez de rechazar a las poderosas divinidades extranjeras que les habian sido impuestas, trataron de incorporarlas al panteón de potencias sobrenaturales con quienes buscaban entablar relaciones de "equilibrio" 24 . Para los indios, en este tipo de relaciones no se estaba excluyendo el compromiso permanente contraído con los dioses andinos locales. En ese sentido, el número de huacas y "hechiceros" locales, organizados por ayllu, y que el séquito de Albornoz no llegó a cubrir, desmiente la afirmación de que las huacas habian sido abandonadas por sus creyentes ${ }^{25}$. Tal vez era distinto el caso de los principales dioses regionales o suprarregionales, debido a que su prestigio dejaba atrás las afiliaciones étnicas locales, su asimilación al Estado incaico los había desacreditado, y sus santuarios y riquezas habían sido saqueados. Sin embargo, conforme fue manifestándose más nítidamente el conflicto fundamental entre la sociedad europea y la andina, ¿quién podía dudar que ponerse al servicio de los patrones sobrenaturales de los colonizadores, sin respetar los derechos de algunos dioses nativos, no contribuiría al debilitamiento de los dioses y las sociedades andinas en su conjunto?

El Taki Ongoy condenaba el acomodo a la presencia europea y definía las opciones de los pobladores andinos en términos drásticos. Toda cooperación con los europeos o su Iglesia, aunque se permaneciese fiel en espíritu a las huacas locales indígenas, colocaba al individuo en el ámbito de posibles destructores de los dioses andinos. El conflicto de base entre los intereses europeos y andinos limitaba así las estrategias religiosas a categorías absolutas. Los taquiongos hablaban en nombre de las principales huacas antes desacreditadas y de las huacas menores que eran sus aliadas, llamando a los indios a reformarse, a expulsar todo deseo de aplacar a los prestigiosos dioses cristianos, y a superar cualquier crisis de desconfianza hacia el poder de los dioses andinos. 
Este tipo de oposición a los vínculos culturales hispánicos permitiría a la comunidad asumir un compromiso más sólido con las lealtades y relacioncs andinas. Al retomar decididamente, bajo supervisión de los taquiongos, la práctica de antiguas obligaciones ceremoniales, las comunidades nativas obtendrían nuevamente el favor de las revigorizadas huacas andinas y vivirían en salud y prosperidad. ". . . que ayunasen cinco dias en sus formas como lo tenyan de costumbre en tiempo del ynga no comiendo sal ny mayz ny teniendo copula con sus mugeres. .."26. Se divulgaron prácticas como ésta, con el propósito ritual y tradicional de equilibrar las relaciones de reciprocidad con los dioses. En ese momento, sin embargo, las celebraciones rituales adquirieron una función social que se definía en términos de la lucha contra el colonialismo. Su objetivo era la desaparición de los vínculos con la sociedad colonial y el establecimiento de lealtades, relaciones y valores exclusivamente andinos ${ }^{27}$.

El corolario de la resistencia a la sociedad hispánica era la solidaridad con el mundo andino. Sin embargo, aqui también el Taki Ongoy llamaba a introducir cambios que planteaban difíciles dilemas de indole moral. Por un lado, la tendencia del modo de producción andino había sido dividir a la gente en ayllus, comunidades y grupos étnicos rivales. De otro lado, la conquista española creó condiciones que debilitaron los medios de cohesión tradicionales. El culto a los principales dioses regionales o supraétnicos se tornó probablemente más difícil e irregular, amenazando la dinámica con dividir a la sociedad nativa en clases opuestas - una élite nativa vinculada a la estructura de poder colonial y a las relaciones hispánicas de propiedad y trabajo, y un campesinado indígena en cuya mano de obra se sustentaban las élites nativas y demás señores coloniales. Aunque siempre hubo un germen de contradicción clasista en las relaciones entre kurakas y ayllus, los primeros poseían teóricamente privilegios y autoridad por cuanto se les reconocía la calidad de custodios de la identidad e intereses colectivos de sus "familias". En las sociedades a pequeña escala, los imperativos comunalmente aceptados frenan la đinámica de clases incipiente. La penetración colonial española representó entonces un impulso que fertilizó el creçimiento y desarrollo del embrión que albergaba las contradicciones de clase, produciendo como subproducto una crisis de confianza en las antiguas costumbres que debilitó la unidad interna de 'la vida comunal. La adhesión mostrada por los kurakas hacia símbolos hispánicos y su colaboración con los colonizadores, los vinculaban con los yanaconas e indios del ayllu socialmente móviles, cuyas estrategias y aspiraciones amenazaban convertirlos en agentes del colonialismo. El hispanismo y la colaboración con el régimen colonial eran elementus que atentaban contra el prestigio o legitimidad de los dirigentes, al conside- 
rar su pucblo que estaban actuando en favor de los españoles y en contra de sus propius intereses y expectativas.

El Taki Ongoy condenaba las dinámicas tendientes a separar individuos y comunidades nativas en campos opuestos. Las huacas y taquiongos expresaban una suerte de ansiedad corrosiva frente al hecho de que los nativos que adoptaban estilos hispánicos de religión, vestimenta, alimentación y costumbres estuvieran convirtiéndose en enemigos vinculados al colonialismo y la cristiandad. Aparte de simbolizar la renovación del compromiso comunal para efectuar intercambios con los dioses andinos, las reuniones rituales de carácter antihispánico que dirigían los maestros del Taki Ongoy servían para presionar a los indios cuyas tendencias hispanizantes los apartaba de la comunicad y sus luchas. Unicamente participando en los rituales de reivindicación y purificación que dirigían los taquiongos, podrían los nativos cristianos - aun cuando hubiesen cumpliuo con sus obligaciones paganas-aplacar la ira de las huacas. Sólo despojándose de todo elemento hispánico podrían los inciios relativamente "aculturacios" - los kurakas, en particular- yanar nuevamente la confianza de sus desconfiacios paisanos. Sólo sometiéndose a tales presiones podria la incipiente clase de indios hispanizados evitar su destrucción junto con los españoles y unirse a los nativos en su tránsito hacia la salud, la abundancia y la autonomía ${ }^{28}$.

El Taki Ungoy' buscaba la solidaridad trascendiendo no solamente las divisiones de clase que recién emergían, sino también las aesuniones tradicionales que seguian lineamientos comunales y étnicos. Sin lugar a dudas, el llamado de Taki Ongoy' a la toma de conciencia de una unidad panandina cra revolucionario en términos del pensamiento e identificación tradicionales. En su lucha contra el dios cristiano, las huacas mismas constituian un ejemplo: los taquiongos hablaban en nombre de "Titicaca y Tiahuanace Chimboraco Pachacamac Tambotoco Cauauilea Caruarco y otras mas de sesenta o setenta guacas"29. En igual sentido, la aliliación, a un ayllu o a grupos étnicos que rivalizaban con otros sistemas de parentesco, debía supeditarse a la importancia que la nueva realidad imponía de unificación de todos los nativos en una sola casta subordinada al régimen español. Por primera ve $z$ los nativos comenzaron a considerarse seriamente como "indios". Lus predicadores del Taki Ongoy se referían a "los indios" y "las huacas" como si se tratase de categorías nuevas y menos particularizadas de intereses e identidad ${ }^{30}$. Resulta así significativo que los taquiongos designaran una encomienda de características multiétnicas como zona de concentración central, donde acudian indios procedentes de diversas encomiendas y grupos étnicos $^{31}$. Al igual que las huacas habían depuesto rivalidades latentes para hacer de los Andes un lugar seguro para los dioses y el pueblo indigena en su 
conjunto, así también debían los indios adoptar una posicion común frente a los europeos. Lo cual podría traducirse como el deseo que los pobladores andinos proyectaban sobre sus dioses para dejar de lado divisiones y conflictos estructurales que aumentaban su susceptibilidad al dominio colonial ${ }^{32}$.

Los dirigentes del Taki Onqoy buscaban demostrar que en una confrontación con el Dios cristiano, las huacas andinas unidas inevitablemente ganarían. Sin embargo, tampoco consideraban como algo insignificante el poderío del Dios cristiano, en vista de la victoria española en Cajamarca y otros lugares, el dominio que aún ejercían los colonizadores y las ventajas que podían derivarse de una posible colaboración con los hombres y dioses hispánicos. Los taquiongos admitían "que Dios hera poderoso para aver fecho [al reino español de] Castilla e a los españoles e a los mantenimientos que en Castilla se crian"'33. Según la visión andina, la fortuna material de quienes intervenían en una guerra reflejaba en gran medida el poderío de sus dioses. El triunfo de los colonizadores, que representaban al distante reino de Castilla, era una demostración del poderío de su deidad principal: Dios.

En vez de negar enfáticamente el poderío del Dios cristiano, los taquiongos utilizaron un argumento de base material para demostrar las fuerzas que podían contraponer los dioses nativos. Si era cierto que los dioses españoles eran pródigos abastecedores y reinaban soberanos en España, en tanto conductores del proceso de creación material, entonces no podía negarse la superioridad de las huacas andinas en el Perú, donde por sí solas eran sostenedoras de las bases materiales de la vida. En los Andes, "las huacas habían hecho a los indios, a esta tierra y a los mantenimientos que de antes tenían los indios; $y$ asi quitaban a [Dios] su omnipotencia"34. Para una economía en donde los colonizadores permanecían como elementos extraños, y requerían de aliados como los kurakas y de relaciones al estilo andino para supervisar la producción y obtener un excedente, un argumento de esta índole expresaba una profunda verdad colonial. Hasta ese momento los europeos no lograban integrarse de manera funcional como partes necesarias a la sociedad y economía locales ${ }^{35}$. Si recordamos que en la sociedad andina tradicional, son estrechos los vínculos entre las relaciones religiosas, el trabajo cooperativo y la producción económica, comprenderemos por qué los pobladiores andinos, incluso en la actualidad, tienden a trazar paralelos entre las relaciones de los seres humanos y la sociedad y las existentes entre sus dioses en el cos$\operatorname{mos}^{36}$. Los europeos resultaban elementos ajenos a la buena conducción de la economía nativa y ello comprobaba de manera similar por qué eran fundamentalmente ajenos e impotentes también sus dioses. En ese sentido, muchos de los principales dirigentes sostenían que: "no hera Dios el que les daria [a los indios] sus comidas" 37 . 
Por ello las relaciones tanto con los dioses hispánicos como con su gente cran en lo fundamental prescindibles. Señalaban el cristianismo como algo extraño, innecesario y comprobadamente inferior. Los taquiongos "metian una cruz. . . a un rincon c. . hablaban en la dicha casa con sus guacas". Allte sus oyentes, decian: ". . . veis como ese palo [cristiano] no hablo por la cruz. . . este [la huaca andina] que nos habla. . . es Nuestro Dios y Criador y a este hemos de adorar e creher". Los dioses que les habian sido enseñados por los cristianos cran "cosa de burla" 38 . Al reconocer, de un lado, que la colaboración con los españoles, las rivalidades étnicas y las oposiciones de clase emergentes eran debilidades que contribuian al dominio colonial, el Taki (Mncy. les reconocía de otro lado una fuerza fundamental a los pobladores y dioses nativos: la administración y organización interna de la producción económica en los Andes permanecía principalmente en sus manos. Los estrechos vínculos entre la dimensión material y religiosa de la vida permiticron a los taquiongos "demostrar" la superioridad en el Perú de los dioses andinos, en virtud de la vitalidad económica, la autoconfianza y la superioridad esencial de los pobladores andinos.

El Taki Onqoy hablaba de verdades que podian ser apreciadas por todos los sectores de la sociedad nativa, y evocaba dilemas morales que concernian casi a todos. Las contradicciones del colonialismo afectaban al indio del ayllu, al kuraka y al yanacona. El descontento por las consecuencias de la cooperación entre partes con intereses contrapuestos, el rechazo a continuar colaborando con la gente o los dioses europeos, la reizindicación de las normas y relaciones tradicionales de la comunidad o "familia", el deseo de superar divisiones que mermaran la solidaridad para hacer frente a la explotación, el sueño de una convulsión que anunciaría un ciclo nuevo y purificado de la historia: todos eran planteamientos tendientes a canalizar la energía reprimida de los desencantados indios del ayllu en los años de 1560. No en vano eran ellos quienes soportaban el peso sobre el cual se basaba la exigente sociedad y economía coloniales.

En las verdades y dilemas morales que expresaba el Taki Onqoy había también un llamamiento a los kurakas. En tanto guardianes del bienestar comunitario y mediadores cuyo éxito dependía de cuán "influyentes" eran sobre sus paisanos, los miembros de la élite nativa no podían permanecer indiferentes ante el descontento o tendencias perjudiciales a la sociedad del ayllu. Es probable más bien que sintieran alarma ante las demandas de los españoles de mano de obra para los asientos mineros distantes. Este tipo de Jemandas ayudaban a erosionar la efectiva red de energía humana de que uisponía la sociedad local y, en ese sentido, terminarían amenazando las prerrogativas tradicionales de los señores nativos. A los kurakas que busca- 
ban liberar la sierra andina del sistema de encomiendas, el Taqui Onqoy les prometía una utopía verdadera: sociedades locales autónomas, libres de incas y de europeos, y bajo el mandato único de sus jefes naturales ${ }^{39}$.

Los yanaconas tampoco permanecieron indiferentes al mensaje del Taki Onqoy. Su dependencia personal de amos europeos los dejaba vulnerables a humillaciones, abusos y obligaciones laborales que tornaban casi imperceptible su diferenciación de los indios del ayllu. Podemos asumir la hipótesis que con el auge minero en los años de 1560, fue inminente el recurrir al empleo de yanaconas como esclavos indígenas que complementasen el trabajo de los indios de las encomiendas ${ }^{40}$. De otro lado, su aislamiento individual de ayllus, comunidades y paisajes humano divinos de la sociedad tradicional, los alienaba del subsuelo colectivo que, en la cultura andina, nutria la identidad, la psiquis y el afecto individuales. Al igual que en otras zonas colonizadas, el vacio social y psicológico derivado de dicha "individualización" podía crear una profunda crisis espiritual. En los rituales antihispánicos del Taki Onqoy - que seguían pautas de ceremonias y costumbres andinas tradicionales - los yanaconas podían recobrar, junto con los indios y kurakas del ayllu, el sentido perdido de inmunidad comunal frente a las corrupciones del colonialismo español ${ }^{41}$. En tanto "forasteros" de la sociedad del ayllu, los yanaconas que desconfiaban de la cooperación entre nativos y blancos podían adquirir una perspectiva singular sobre las consecuencias del colonialismo para los grupos nativos en su conjunto, como una casta de indios mis que como un conglomerado heterogéneo de ayllus y grupos étnicos. Al re- formular su vinculación activa con la sociedad del ayllu, los yanaconas estaban en condiciones de hacer suyo uno de los principales postulados del Taki Onqoy: que en la experiencia compartida de volverse "indios" quedaban atrás las rivalidades étnicas y entre ayllus que tradicionalmente habían enfrentado a los grupos nativos entre sí.

El discurso del Taki Onqoy en consecuencia reflejaba las necesidades cada vez más urgentes percibidas por toda la sociedad nativa, en un momento de crisis, cuestionamiento y anhelo de cambio. Era la expresión de dolorosas realidades que, de manera más difusa e incipiente, comenzaban a alarmar a las sociedades nativas y sus integrantes hacia los años de 1560. A partir de dichas realidades, el movimiento sometía a un juicio moral las formas anteriores de adaptación de los nativos a la conquista española, señalándolas como perjudiciales y destructivas, por lo que se exigía un cambio. Finalmente, el Taki Onqoy prometía a sus seguidores una esperanza de superación del desaliento causado por divisiones y debilidades, y el ingreso a una nueva cra libre del dominio colonial. Por todo ello, no resulta sorprendente que casi la totalidad de miembros de la sociedad nativa se mostrasen dispuestos a adoptar semejante herejía subversiva. 


\section{LA VULNERABILIDAD DEL MOVIMIENTO}

Su desenvolvimiento no fue sin embargo simple. El Taki Onqoy no exigía un compromiso de lealtad homogéneo por parte de todos los indios, ni siquiera de sus propios seguidores. Su llamado era más bien de resistencia a los espanoles y al hispanismo, de reivindicación del mundo andino nativo y de solidaridad entre todos los indios, precisamente en virtud de la existencia de múltiples fuerzas sociales que pugnaban en dirección opuesta. Las divisiones y los conflictos en el interior de la sociedad nativa no desaparecieron con el anuncio de un próximo cataclismo, ni tampoco desapareció la tentación de aliarse, o cuando menos apaciguar, a los colonizadores. En Taki Onqoy exacerbó una crisis moral en la sociedad indígena debido precisamente a que en un momento de gran desilusión y recelo, pasó a condenar estrategias, adaptaciones y tradiciones a las que, en la práctica, muchos nativos difícilmente podrían renunciar. Al avizorarse la victoria española, incluso adherentes de la secta iniciaron la búsqueda de un patrono europeo benigno que los protegiese de un castigo severo ${ }^{42}$. Desde un inicio, hubo indios que desafiaron las reglas del Taki Onqoy' al aliarse activarnente con los colonizadores. Un kuraka llegó a traicionar a dos dirigentes de la secta, y la comitiva de Albornoz contó con lus servicios de funcionarios e informantes indigenas en su campaña antiidolatrias ${ }^{43}$. Como se verá posteriormente, la dinámica de clase, etnicidad y colaboracionismo que fueran objeto de ataque en los años de 1560, condicionaron asimismo la composición social, el liderazgo y la cohesión del movimiento para hacer frente a las presiones.

Al administrar un castigo a los indios hallados culpables de participación en la herejía, las autoridades españolas reconocieron diferentes niveles de liderazgo, compromiso y amenaza potencial. La campaña de Albornoz envió al Cusco a jefes e indios notables de comprobada actividad, junto con dirigentes e "inventores" de la secta, para ser castigados y que se confesasen públicamente; otros indios ciel ayllu y seguidores del movimiento permanecieron en sus localidades, siendo obligados a escuchar sermones que denunciaban sus errores y explicaban el camino a seguir para la salvación católica ${ }^{44}$. Las relaciones de inspección establecían diferencias entre los principales predicadores y sus cómplices (predicadores, maestros, dogmatizadores) y el grupo más numeroso de taquiongos, quienes constituian un núcleo activo de seguidores ${ }^{45}$. Los personajes subversivos más peligrosos sufrieron el exilio temporal o permanente de sus lugares de origen. Algunos fueron puestos a trabajar en la iglesia o en el hospital de la ciudad de Huamanga; otros fueron designados para servir a los curas en otras encomiendas. Los dirigentes menores fueron sentenciados por Albornoz a habitar casas especiales en 
cercanía a sus respectivas iglesias distritales, donde debían prestar servicios en forma indefinida. La gran mayoría de taquiongos no sufrieron el extrañamiento de sus encomiendas y ayllus, pero su herejía le sirvió a la Iglesia para incrementar sus exigencias respecto a prestación de mano de obra. Fue el caso de noventa y cinco taquiongos de Huacaña (Soras) que fueron obligados a concurrir tres días a la semana donde el párroco a fin de recibir instrucción religiosa y servir a la iglesia de la localidad cercana de Morocolla, "en lo que fuese necesario"

Las contradicciones de clase latentes dentro de la sociedad local hicieron que la relación entre las élites nativas tradicionales y la herejía popular fuese en el mejor de los casos problemática o ambivalente, y en el peor caso antagónica. A pesar del gran apoyo con que contó el Taki Onqoy entre los kurakas y élites menores, la información de que disponemos sugiere que, en tanto grupo social, los jefes nativos no arriesgaron ni su influencia ni su prestigio mediante un liderazgo o respaldo decididos del movimiento. En el Cusco, los principales dirigentes de la secta "confesaron" públicamente haber propagado una superchería: "ellos no savian cosa alguna sino que por ser pobres e ganar de comer por las ofrendas" 47 . En tanto pueda otorgarse alguna credibilidad a tales confesiones forzadas, contradicen la educación que colocaría a los principales y más prósperos kurakas entre los dirigentes del movimiento. Son pocos los kurakas conocidos que aparecen en las relaciones de dirigentes claves ael Tuki Onqoy condenados al exilio ${ }^{48}$. En las regiones importantes de Lucanas, aparentemente los kurakas adoptaron posiciones divergentes en torno al Taki Onqoy, a pesar que muchos de ellos participaban en prácticas "idólatras" convencionales. En Lucanas Laramati, por ejemplo, tanto los jefes de Guacguas como los de Caroancho fueron hallados culpables de idolatrías en general, habiendo los pobladores de ambos yrupos participado en el Taki Onqoy. En las relaciones de taquiongos hallados culpables, sin embargo, se incluye a los jefes de Guacguas pero no así a los de la cercana Caroancho. En la división Hanna (Superior) de Lucanas Laramati, ocho de diez jefes hallados culpables de adoración a las huacas comunes de la localidad, fueron también acusados de tener conexiones con el Taki Onqoy. En el grupo Hurin (Inferior), sin embargo, sólo cinco de los once jefes habian participado ${ }^{49}$. Un kuraka de la encomienda de Juan de Mañueco, lugar de concentración central de los conspiradores, llegó incluso a conducir hasta Huamanga a dos importantes taquiongos para que fuesen castigados ${ }^{50}$. Es significativo notar que las autoridades españolas formulaban sus acusaciones a muchos kurakas y miembros de élites menores en términos que sugerían la existencia de una alianza con la secta y no de un franco liderazgo del movimiento. La inspección a cargo de Albornoz, al castigar a los jefes, 
solía acusarlos no de "predicadores", "macstros", "inventores" o "aogmatizadores" sino de "consentidores" o "encubridores" que probablemente habían refrenado o puesto en peligro a la secta ${ }^{51}$ -

La evidencia en su conjunto no sólo manifiesta diferencias entre las élites nativas tradicionales y los instigadores de la secta ${ }^{52}$, sino que además sugicre que entre ellos existieron vínculos ambivalentes, oposiciones latentes y francos conflictos. Se puede recordar que los propios kurakas eran objeto de presión popular para que abandonasen la hispanización cultural en favor de la solidaridad para hacer frente al colonialismo. Como grupo social, su relación con el movimiento varió desde la traición a los europeos al apoyo renuente con miras a preservar su ubicación dentro de los grupos de parentesco, pasanuo por un apoyo más decidido, y llegando en algunos casos a ejercer activamente el liderazgo. Por mucho que los afectase la intensidad cada vez mayor de la oposición entre nativos y blancos en los años de 1560, y aun cuando el Taki Onqoy' representase una especie de utopía para los jelies de ayllus y comunidades libres, eran los kurakas quienes más perderían si el movimiento fracasaba en extirpar a los europeos y servía en cambio para desatar sus iras y venganza. Por muy primitiva o embrionaria que fuese su distinción como clase de las familias y ayllus de la comunidad, y por muy vulnerables que hubiesen sido el mensaje del Taki Onqoy, las recompensas o sanciones a que se harian acreedores los diferenciaron en sus opciones frente a las de sus paisanos. No importaba cuán leal y genuino era su compromiso con el movimiento antihispánico; su potencial en tanto clase integrada a una estructura de puder colonial donde se unian diversos "señores" en la mutua explotación del campesinado, era un factor que impartía una ambivalencia especial a sus decisiones.

L) Taki Onqoy era literalmente un estallido popular, que no podía ser controlado fácilmente por élites o relaciones tradicionales, y que se originaba parcialmente en la rivalidad u oposición a las élites nativas gobernantes. Ll carácter del movimiento al manifestarse "muy deshordenadamente"53 violaba las formas convencionales de control características de la religión andina. En base a la evidencia disponible, puede decirse que la élite religiosa tradicional no actuó como fuerza primordial detrás del movimiento. Dillchos de sus miembros habían llegado a desarrollar un modus vivendi con los curas católicos del lugar, quienes pasaban por alto el paganismo. Lo que is más, Albornoz tuvo conocimiento de concentraciones donde los taquiongus llegaron a asesinar a los curas nativos de la localidad (huacacamayos) ${ }^{54}$. Los conflictos de esta índole enemistaron a los huacacamayos tradicionales, que se hallaban al servicio de los dioses locales, con los taquiongos -incluyendo ¿ los yanaconas marginalus a la comunidad-, quienes cuestionaban su auto- 
ridad al sostener que ellos (los taquiongos) eran voceros de divinidades andinas más célebres y de las huacas en su conjunto.

Si la ambivalencia de las élites nativas frente al Taki Onqoy limitó la fuerza del movimiento, igual efecto tuvieron las desuniones y antagonismos inherentes a una sociedad organizada a través de sistemas rivales de parentesco y etnicidad. El Taki Onqoy hacía un llamado a la unidad panandina a fin de superar dichas divisiones, pero sin un compromiso efectivo y organizado por parte de los jefes de los diversos ayllus y comunidades, esto difícilmente podría ponerse en práctica. En la medida que los nativos no podían expresar su hostilidad anticolonial directamente, es posible que surgiese un impulso interno hacia el conflicto y la violencia dentro de la sociedad nativa ${ }^{55}$. En todo caso, la reaparición en los años de 1570 de serios conflictos sobre tierras entre grupos étnicamente diferenciados al sur del río Pampas, indicaban las dificultades existentes para suprimir viejas hostilidades que eran básicas en la organización social y económica andina ${ }^{56}$.

Aún en el interior de un grupo étnico, su misma organización descentralizada puede haber contribuido sutilmente a pluralizar los niveles de entusiasmo, lealtad y compromiso respecto a los taquiongos, teniendo en cuenta que los propios jefes tuvieron reacciunes distintas hacia el movimiento. Entre los pobladores de Lucanas Andamarcas, por ejemplo, en las acusaciones vertidas contra sesenta y nueve kurakas y élites menores -muchos de los cuales eran caudillos menores y miembros activos en sus grupos de parentesco- pueden encontrarse algunas claves para comprender dicha diversidad. En los ayllus de Andamarca y Omapacha las élites fueron castigadas simplemente por "consentidiores", mientras que en Uchucayllo lo fueron por "consentidores de la dicha secta y por aver dado favor e ayuda a los dogmatizadores" ${ }^{57}$. Tanto la fragmentación étnica como la incipiente dinámica de clase, fueron elementos de primer orden que contrarrestaron el llamado del Taki Onqoy a la unificación panandina.

Finalmente, la determinación antihispánica aun de taquiongos que se hallaban comprometidos, se vio minada por una curiosa vulnerabilidad interna frente a la derrota o sumisión. Los españoles se jactaban de que muchos indios se habían presentado voluntariamente ante la comitiva de Albornoz para "confesar" sus pecados y pedir clemencia ${ }^{58}$. En muchas de estas "confesiones" había un indudable vuelco táctico al anticipar los nativos el triunfo de la campaña antiidolatrías de Albornoz. Pero no debemos excluir de manera automática la posibilidad que exitiesen motivos de genuino remordimiento. Teniendo en cuenta las divisiones internas de la sociedad nativa $y$ la victoria de los cristianos en Çajamarca, la decisión de abandonar por completo una actitud de colaboración, implicaba grandes riesgos si los coloniza- 
dores y sus dioses demostraban una vez más que eran más fuertes. Los taquiongos nunca negaron rotundamente el poder del Dios de los cristianos; se limitaban a señalarlo como enemigo implacable de las huacas nativas, las que pose ían la fuerza suficiente para vencerlo. Uno de los ejemplos más saltantes de "arrepentimiento" voluntario entre los taquiongos fue el de un grupo de autodenominadas "santas", que habían adoptado nombres como María y Magdalena ${ }^{59}$. Desde una visión andina, estas santas cristianas formaban parte de un panteón de huacas hispánicas a cuya cabeza estaba Dios. Estas mujeres -a quienes los taquiongos veneraban en calidad de santas cristianas más que de huacas andinas- eran expresiones de un deseo pe rcibido por el núcleo del movimiento Taki Onqoy de aliarse con ciertos elementos del poder sobrenatural hispánico mientras, de otro lado, se libraba la batalla contra Dios. El intento de ganar el favor de estas divinidades menores, en medio de una guerra anticristiana, ponía de manifiesto una crisis de confianza en la capacidad de los dioses andinos para controlar por sí solos el curso de los acontecimientos.

Como resultado, una cierta ambivalencia -común a situaciones coloniales-impregnó el rechazo del resurgimiento nativista hacia los vínculos hispánicos, y diluyó su determinación ante la presión española. Aunque en los años de 1560 había un sentimiento generalizado de desilusión respecto a los europeos, el asumir una actitud de colaboración podía representar ciertas ventajas sobre posturas conflictivas que invitaban a tomar represalias. El Taki Onqoy se alzó en respuesta a un dilema moral que emergía justamente debido a que los impulsos antihispánicos de los nativos se veían moderados por sus permanentes tendencias a aplacar a los colonizadores y a sus poderosos dioses.

Las verdades del Taki Onqoy ejercieron una influencia contagiosa sobre todos los sectores de la sociedad nativa, pero al mismo tiempo dejaron al descubierto las debilidades que acechaban al movimiento. Al condenar a los indios hispanizantes que se habían plegado al poder colonial, junto con los antagonismos internos que tradicionalmente dividian a los ayllus y grupos étnicos, y, en general, las adaptaciones para colaborar con los colonizadores y sus dioses, el Taki Onqoy estaba señalando precisamente las fuerzas que erosionaban su propia capacidad para desafiar a la sociedad colonial. La incipiente dinámica de clases, la división étnica y el colaboracionismo fueron factores que ensombrecieron la herejía popular de Huamanga, limitando su eficaz proyección sólo a aspectos espirituales. El primer factor tornó ambiguos y contradictorios los vínculos entre la élite y el movimiento; el segundo mermó la capacidad de los nativos para organizar una fuerza o estrategia verdaderamente unificadas; el tercer factor fue motivo de tormento para los 
nativos sensibles al mandato moral del Taki Onqoy de autopurificación de vínculos con el mundo hispánico.

\section{EL MILENARISMO COMO CRISIS SOCIAL}

Con la posesión de los nativos por los dioses andinos, los sueños radicales de un cataclismo cundieron por toda la sociedad nativa, sin dejar incólume a ningún sector La fuerza ideológica del núcleo del "milenarismo. revolucionario" -entonces y ahora, en los Andes o en cualquier otro lugar - ha sido la visión desesperada de una inminente y total transformación que, en virtud del poder de fuerzas sobrenaturales y de la propia purificación moral de los insurgentes, en poco tiempo destruirá un orden social maligno engendrando en su lugar un mundo nuevo y perfecto. Históricamente, los movimientos de este tipo se han dirigido a los grupos sociales donde reinaba el descontento y se experimentaba una profunda crisis de confianza. Son grupos que, además de considerar difícil o poco práctico el lanzarse en un asalto político o militar más directo contra las fuentes de su descontento, han perdido confianza en la integridad moral de sus propias vidas. La combinación de descontento radical, impotencia política y dudas internas, imparte a tales crisis un carácter especialmente espiritual o moral, aunque la disconformidad tiene como base procesos socioeconómicos. Particularmente en situaciones coloniales, una crisis de esta índole suele experimentarse como una profunda ambivalencia entre dos modos competitivos de relaciones y valores. El prestigio y atractivo prevalecientes del mundo de poder y riqueza del hombre blanco, añaden una terrible prueba de convicción interna a la ya pasada carga de opresión e impotencia política ${ }^{60}$.

El Taki Onqoy fue la respuesta a la aparición de una crisis precisamente de estas características en Huamanga. Hacia la década de 1560, una mezcla explosiva de temibles percepciones, impulsos subversivos y graves recelos dio nueva forma a múltiples actitudes de los nativos hacia sí mismos y respecto a las alianzas entre nativos y blancos. Los taquiongos proclamaban abiertamente que las alianzas postincaicas entre nativos y españoles habían constituidc una fuente de males más que una estrategia para la supervivencia y la adaptación. En su fogoso mensaje sostenían que sólo partiendo radicalmente de estrategias y posiciones del pasado podían las castas de "indios" emergentes purificarse a sí mismos, y revertir el catastrófico destino que los amenazaba. Como hemos visto, las fuerzas sociales existentes continuaron sin embargo empujando a los indios hacia direcciones que el Taki Onqoy condenaba. A pesar del arraigo conseguido por la herejía en to- 
da la sociedad nativa, los taquiongos no pudieron neutralizar por completo la obstinada dinámica de clase, la etnicidad y el colaboracionismo que debilitaban el potencial político de cualquier brote de rebeldía. Tampoco lograron que cediera la crisis interna de confianza y valores, la cual tornaba difícil hasta para ellos mismos el rechazo irrevocable de todo vínculo hispánico. Las limitaciones al éxito del Taki Onqoy ponían de manifiesto el impasse de desilusión radical, debilidad política e incertidumbre moral en que se había autoconfinado la sociedad nativa en los años de 1560.

Fue precisamente la crisis espiritual creada por este impasse -y no las supuestas tensiones de un fracaso anárquico o una desorganización, ni el pretendido empuje prepolítico inherente a una protesta campesina ${ }^{61}$ - la que explica por qué cundió en Huamanga una revuelta milenaria que enfatizaba la reforma moral. A través de las alianzas postincaicas, las sociedades nativas de Huamanga -especialmente en el sur, en donde la herejía prendió con mayor ímpetu - habían conseguido preservar un grado de vitalidad económica y de coherencia interna que contradice las imágenes de anomia, desorganización o "desestructuración" que se usan con frecuencia para explicar el milenarismo revolucionario. El profundo descontento que imperaba en Huamanga en la déçada de 1560 tenía origen no tanto en las presiones de desorganización social o empobrecimiento, sino más bien en una creciente toma de conciencia, entre los grupos que se habían adaptado con relativo éxito a las condiciones coloniales, de que las contradicciones del colonialismo los conduciría a resultados tolerables. Tampoco podemos sostener que los sueños milenarios que dominaban el carácter de la subversión en Huamanga, reflejaban una predisposición de gente del agro premoderno a trazarse formas ineficaces, "prepolíticas", de lucha contra la opresión o las privaciones. Las sociedades andinas cuyas circunstancias las diferenciaban ke lluamanga, al parecer eran perfectamente capaces de organizar formas cic lucha político-militares contra el colonialismo. Fue el especial carácter moral de la crisis experimentada en Huamanga, y no la cualidad inevitablemente prepolítica de la protesta entre sociedades arcaicas, el factor que engendró el milenarismo. Es obvio que la incapacidad de los fragmentados pobladores de Huamanga para encauzar organizadamente su descontento en una guerra contra los españoles contribuyó profundamente a su crisis espiritual.

El Taki Onqoy ofrecía a sus creyentes un camino para superar la desmoralización inherente a los sentimientos de desencanto 2 impotencia y recelo interno que atormentaba a la sociedad nativa. A través de la guerra desatada por los dioses nativos y del retorno de sus fieles a la pureza moral, se obtenuría el restablecimiento de un pasado prístino exento de corrupciones co- 
loniales e incaịcas. En términos, prácticos, el camino a la liberación se centraba más bien. internamente en los delitos de la sociedad nativa, que externamente en lós agentes europeos del mal. La reforma moral y la resistencia pasiva, y no la organización para un atáque humano directo contra los colonizadores, serían los elementos conducentes a la utopía andina.

2 Lo que diferenció la crisis milenaria que inflamó la zona sur de Huamanga de otros movimientos anticoloniales fue este predominio de un arama moral con enfoque interno. Los neoincas, cuyo baluarte era la zona selvática de Vilcabamba, adoptaron estrategias políticas y militares más directas - una combinación de guerra y diplomacia - en sus enfrentamientos con los europcos' en los años de 1530 en adelante. A pesar que las inspiracionics religiosas nativistas desempeñaron un importante rol ideológico en sus incursiones militares y conspiraciones insurreccionales, su independencia y postura anticolonial bastante consistente los apartaron de una crisis de purificación moral. Al igual que las sociedades locales de Huamanga antes de experimentar una crisis de confianza, los neoincas demostraron receptividad hacia el bagaje cultural hispánico. Aun durante sus periodos de mayor militancia, no llegaron a rechazar los símbolos ni la religión hispánica. Y no dudaron cn recurrir a la agresión para saquear u obtener en trueque mercancías españolas, en particular caballos y armas que mejoraban su eficacia militar ${ }^{62}$.

Algo similar ocurrió con los huancas en el norte de Huamanga, quienes en 1565 tramaron un cruento levantamiento. Los huancas eran enemigos declarados de los incas y habían llegado a aliarse con los conquistadores españoles. Pero, al igual que las sociedades huamanguinas, aparentemente atravesaban por una crisis de desengaño respecto a los españoles.

El Taki Onqoy tal vez desempeñó un significativo rol ideológico entre ellos; sin embargo, el peso otorgado a la reforma interna y a la resistencia pasiva y el haber formulado el enfrentamiento con los españoles dentro del reino de lo sobrenatural, no definieron la naturaleza de su subversión. La solución de los huancas a su descontento asumió la forma de una conspiración militar, coordinada con sus antiguos enemigos incas y concebida como parte de una revuelta mayor que abarcaría toda la sierra andina. Al igual que los neoincas, los huancas lograron salvar el impasse de extremo desencanto, debilidad organizativa e incertidumbre moral, que estaba a la base de la crisis espiritual que cundió en Huamanga. Por haber sido un reino regional poderoso, estratégicamente importante y étnicamente unificado -distinto por completo a las sociedades huamanguinas que se caracterizaban por su diversificación étnica-, pudieron organizarse vastamente centrándose en el liderazgo de sus diversos jefes étnicos reconocidos. En ese sentido, su eficacia como reino étnico con un ejército regional independiente era mayor que la 
de las fragmentadas sociedades de Huamanga. Y fueron más allá de los huamanguinos, al lanzarse a pelear decididamente en los enfrentamientos armados de los españoles, con lo cual ganaron notoriedad como ejércitos étnico aliado. La experiencia, además de familiarizarlos con la cultura hispánica, les permitió a los huancas adoptar como propias la técnica y la tecnología militar de los españoles. En vez de "purificarse" culturalmente de elementos hispánicos, optaron por instalar fábricas primitivas donde producian en cantidad picos, hachas y otras armas de origen español, preparándose para la guerra anticolonial. En vez de reafirmar una lealtad rígida y absoluta hacia todas las costumbres andinas, los jefes huancas dieron prioridad a las tareas de organización. Se rehusaban a redistribuir los excedentes agrícolas entre las familias 0 ayllus necesitados, prefiriendo en cambio almacenar alimentos en gran escala para responder a las necesidades que creara la guerra ${ }^{63}$.

La amenaza secular que planteaba la convulsión espiritual de Huamanga era menos inmediata que la representada por los esquemas militares de los huancas y los neoincas. Podría afirmarse entonces que el énfasis puesto por el Táki Oncoy en aspectos internos como la purificación moral era políticamente derrotista; que su rechazo a la sociedad española era ambivalente; que los sueños milenarios fracasaron, en términos prácticos, en salvar las debilidades $y$ resolver los dilemas que habian generado en primera instancia aquella profunda crisis espiritual. En este sentido, el Taki Onqoy representó para los pobladores de Huamanga la renovación espiritual y la esperanza, pero no asi una vía hacia la efectiva liberación.

Con un argumento como el anterior no debe, sin embargo, olvidarse que la fiebre milenaria que cundió en Huamanga tue un serio desafio para la emergente sociedad colonial. Al margen del contenido de su enfoque hacia el interior, el contexto y las consecuencias históricas del Taki Onqoy produjeron importantes repercusiones económicas, políticas y militares para la sociedad en su conjunto. Desde el punto de vista económico, los colonizadores dependían en gran medida de una alianza con las élites nativas para ganar acceso a los bienes y la mano de obra explotable, pues aún no habian erigido un sofisticado aparato estatal para forzar a los jefes nativos a proveer, consistente y regularmente, de bienes y de mano de obra a la empresa colonial. Es indudable que el Taki Onqoy estimuló el brote de hostilidades, el rechazo a la cooperación, el sabotaje y la resistencia pasiva, elementos que frustraron el desarrollo económico de Huamanga en la década de 1560. Politicamente, la herejía amenazó con revertir las estrategias de cooperación, exhortando a las lealtades indígenas de grupos étnicos, élites nativas y yanaconas hispanizantes que alguna vez sostuvieron al régimen colonial. Aun cuando la rebelión se centrara principalmente en aspectos religiosos, estimuló el desa- 
rrollo de actitudes y relaciones que podian mejorar las perspectivas de éxito para la rebelión indígena. Al postular la toma de conciencia respecto a una identidad e intereses compartidos, buscaba superar las divisiones entre grupos de parentesco o comunidades rivales, o entre élites hispanizantes y campesinos indigenas.

Ante la existencia de sociedades indígenas preparándose para la guerra, cualquier movimiento social que incentivara la unidad panandina y el odio a los europeos constituía un peligro militar. Los conspiradores y rebeldes, incluyendo a los neoincas, se aliaron con el Taki Onqoy esperando hallar ahí los medios para invocar a la cooperación militar y poder finalmente derrocar al régimen español ${ }^{64}$. ¿Quién podría haber negado que una movilización basada en el odio anticolonial y en expectativas milenarias y cuya propagación fue contagiosa, no acabaría transformándose en un efectivo ataque militar? El corregidor de Huamanga, al igual que sus similares de Huánuco y Cusco, llegaron a advertir al virrey suplente García de Castro sobre un posible brote insurgente ${ }^{65}$.

El Taki Onqoy fue entonces algo más que una crisis que afectó a la región de Huamanga: formó parte de una crisis mayor que llegó a amenazar al virreinato del Perú en su conjunto. El resurgimiento nativista de carácter religioso amenazó en otro lugares la incursión cristiana en la vida andina. Económicamente, los europeos del Cusco y de Lima tuvieron que enfrentarse a la rebelión de los indios y a su resistencia para cumplir con las demandas de mano de obra. De otro lado, el agudo descenso en la producción de plata de Potosí significaba para la economía colonial la posibilidad de un paro obligado, mientras en Europa eran cada vez peores las dificultades fiscales que España debía afrontar. Políticamente, los kurakas y los curas españoles venían obstaculizando la resolución del debate en torno a si la encomienda debía perpetuarse o abolirse. Además, los celos e intrigas criollos, junto con las conspiraciones mestizas, amenazaban con devastar la sociedad colonial mediante otra serie de guerras civiles. Militarmente, las incursiones de los neoincas en Jauja y Huamanga, sus contactos con las tribus que atacaban las fronteras en Charcas, Tucumán, Chile y el norte del Perú, y el descubrimiento de armas y conspiraciones en Jauja, Andahuaylas y otros lugares, tornaron la insurrección a gran escala en un peligro concreto y no en una simple posibilidad teórica ${ }^{66}$.

En Huamanga, una ambiciosa clase gobemante basó su estrategia política y económica en un sistema de alianzas postincaicas. Pero llegó un momento en que sueños subversivos cundieron entre sus aliados nativos tanto de Huamanga como de otros lugares, amenazando con traer abajo toda la aventura imperial. 


\section{PALABRAS FINALES}

No cabe analizar en este artículo cómo respondió el Estado a la crisis del orden colonial. Basta decir, de acuerdo con Guillermo Lohmann Villena ${ }^{67}$, que en la década de 1560 los españoles tomaron conciencia de la necesidad de buscar formas más eficaces para gobernar y explotar. Como dijo Lope García de Castro, gobernador general del Perú en 1565, "Quanto mas voy mirando las cosas desta tierra tanto mas voy sintiendo quan nece(s)ario es rremediar el mal gobierno pasado ansi en lo espiritual como en lo temporal" ${ }^{\prime 68}$. Es en este contexto de crisis que adquieren su significado histórico las reformas sistemáticas del virrey Francisco de Toledo (1569-1581). Si bien la crisis de los años de 1560 despertó sueños radicales y utópicos en el pueblo andino, dentro del sector colonial planteó la necesidad de reformar la estructura de dominación para así fortalecerla. 
1/ Recuentos sobre el moviniento se encuentran en Luis Millones S.L., "Un movimiento nativista del siglu XVI: el Taki Onqoy" y "Nuevos aspectos del Taki Onqoy": Nathan Wachtel, "Rebeliones y milenarismo"; ambos en Juan M. Ossio A.. ed., Ideologia mesiánica del mundo andino (Lima, 1973), 85-94, 97. $101,105-42$. Los ensayos de Millones aparecieron originalmente en Revista Peruana de Cultura, 3 (1964) e Historia y Cultura, 1 (1965). El ensayo de Wachtel apareció originalmente en su importante trabajo sobre La visión des vain. cus: les indiens du Pérou devant la conquête espagnole, 1530.1570 (París, 1971), 225-82.

Perspectivas sobre el Taki Onqoy y sobre el nativismo e idolatría indígena se encuentran en Millones, "introducción al estudio de las idolatrías", Aportes, 4 (París, abril. 1967), 47-82; Pierrc Duviols, La lutte contre les religions autochtones dans le Pérou colonial: "L'extirpa. tion de L'idolatrie" entre 1532 et 1660 (Lima-París, 1971); R.T. Zuidema, "Observaciones sobre el Taki Onqoy", Historia y Cultura, 1 (Lima, 1965), 137; Franklin Pease G. Y., El dios creador andino (lima, 1973).

Algunas narraciones cortas a cargo de contemporáneos bien informados son: Cristóbal de Molina (1574). Relación de las fábulas y ritos de los incas, en Francisco A. Loayza, ed., Las crónicas de los Molinas (Lima, 1943), 78-84; Cristóbal de Albornoz (c. 1582), "Instrucción para descubrir todas las guacas del Pirú y sus camayos y haziendas". ed. Pierre Duviols, en Journal de la Société des Américanistes, 56, n. 1
(1967), 35-37.

2/ Además de las fuentes mencionadas en la nota 1, Luis Millones ha publicado testimonios de testigos espanoles recolectados por encargo de Albornoz en 1570,1577 y 1584 , al igual que relaciones administrativas de los resultados de la inspección antiidolatrías llevada a cabo por Albornoz en Soras y Lucanas. Millones, ed., Las informaciones de Cristóbal de Albornoz: documentos para el estudio del Taki Onqoy (Cuernavaca, 1971). Al referirme o extraer citas de los testimonios, haré uso de testigos que posean una información especial o de primera mano. Las relaciones administrativas fueron elaboradas en 1584 como una "Relación de Amancebados, Hechiceros y Huacas".

3/ Molina (1574), Relación de las fábulas, 80-81; Millones, ed., Las informaciones, $1 / 18$.

4/ Millones, ed., Las informaciones, $2 / 62,2 / 110$. Creo que "Mal del baile" es la mejor de las diversas acepciones de "Taki Onqoy". Para una discusión al respecto, consultar Duviols, La lutte, 113-14, n. 66.

5/ Millones, ed., Las informaciones, 1/17, 2/109; Molina (1574), Relación de las fábulas, 79-80; Pease, El dios, 72-82; Wachtel, "Rebeliones y milenarismo", 118-19.

6/ Molina (1574), Relación de las fábulas, 80 .

7/ Ver Ibid.: MIllones, ed., Las informaciones, 1/17, 2/109; Josep $M$. Barnadas, Charcas: origenes históricos de una sociedad colonial (La Paz, 1973), 178, n. 152.

8/ Millones, ed., Las informaciones, 2/109.

9/ Ibid., 1/18.

10/ Ibid.. 1/18, 2/46, 2/52-2/53; Moli- 
na (1574), Relación de las fábulas, 80-81; Albornoz (c. 1582), "Instrucción para descubrir", 35-37.

$11 /$ Molina (1574), Relación de lus fábulas, 81.

121 Los cálculos que he realizado sobre un total aproximado de 500 taquiongos (sin incluir a los dirigentes de la secta) entre los pobladores de Soras, indican que alrededor del $550 / 0$ eran mujeres. Ver "Relación dc Amancebados" (1 584), en Millunes, ed., Las informaciones, 4/7$4 / 11,4 / 18-4 / 22$.

$13 /$ Ibid., 2/54. , Varios años más tarde. la inspección del virrey Toledo encontró que la población nativa total de Huamanga era de 122,160 habitantes (excluyendo a Andahuaylas y Parinacochas). Noble David Cook, ed., Tasa de la visita ge. neral de Francisco de Toledo (1570.1575) (Lima, 1975), XXVIIIXXIX.

14/ Millones, ed., Las informaciones, 2/54.

$15 /$ Ver Ibid., 2/62, 2/110, 3/30; Molina (1574), Relación de las fábulas, 82.

16/ Millones, ed., Las informaciones, $1 / 17,2 / 82,2 / 101$.

$17 /$ Ibid., 3/30.

18/ Albornoz (c. 1582), "Instrucción para descubrir". 35; consultar tambien Molina (1574), Relación de las fábulas, 82.

19/ Ver Ossio, ed., Ideología mesiánica; Zuidema, "Observaciones", 137; Pease, El dios.

20/ Para otros ejemplos, consultar Molina (1574), Relación de las fábulas, 13-15, 33; Francisco de Avila (c. 1598), Dioses y hombres de Huaro. chiri, trad. José María Arguedas (Lima, 1966), 39, 47, 49, 149, 151; Pablo Joseph de Arriaga (1621), La extirpación de la idolatría en el Pe. rú, ed. Horacio H. Urteaga (Lima, 1920), 52; Felipe Guaman Poma de
Ayala (1615). Nueva crónica y buen gobierno (París, 1936), 109. 137, 158, 286.

21/ Pedro de Cieza de León (1553). Parte primera de la crónica del Pcrii, en Biblioteca de autores españoles, 26 (Madrid, 1853), Ch. 88.

22/ Ver Pease, El Dios, 51, 65-66; Avila (c. 1598), Dioses y hombres, 117 25; Albornoz (c. 1582), "Instrucción para descubrir", 21.

23/ Ver Albornoz (c. 1582), "Instrucción para descubrir", 37; Cieza (1553), Parte primera, Chs. 72, 56. Una comparación sugestiva se encuentra en Frances Fitzgerald, Fire in the Lake: The Vietnamese and the Americans in Vietnam (New York: Vintage Books ed., 1973). 17-18, 29.

24/ Ejemplos de este enfoque en relación a divinidades extranjeras se cncuentran en Albornoz, (c. 1582), "Instrucción para descubrir", 17, 18, 20, 35; Avila (c. 1598), Dioses $y$ hombres, 130-35, 141.

25/ Consultar las listas citadas en "Relación de Amancebados" (1584), en Millones, ed., Las informaciones, $4 / 5-4 / 6,4 / 11-4 / 16,4 / 27,4 / 41$, 4/42-4/44, 4/36-4/38, 4/33.

26/ Ibid., 2/52.

27/ Sobre las funciones modificadas de las prácticas tradicionales en contextos coloniales, consultar Frantz Fanon, $A$ Dying Colonialism, trad. Haakon Chevalier (New York, 1965).

28/ En relación a los dos párrafos anteriores, ver Steve J. Stern, "Las ideologlas nativistas, la aculturación y las clases sociales". Churmichasun, 4-5 (Huancayo, junio 1977), 25-32.

29/ Millones, ed., Las informaciones, 2/53.

$30 /$ Un pasaje sugerente ( $y$, además, en palabras de un observador español bien informado) que efectuá la contraposición entre "las huacas" $y$ 
"los indios" como categorías unificadas y el "Dios" cristiano y los "españoles", se encuentra en Molina (1574), Relación de las fábulas, 80.

$31 /$ Ver Millones, ed., Las informaciohes, 2/64; cf. AGN, JR, leg. 23, C. 62, 1017, f. $113 \mathrm{r}$.

$32 /$ Cf. Peter Worsley, The Trumpet Shall Sound: A Study of 'Cargo' Cults in Melanesia (2da. ed., New York, 1968), 236-38.

33/ Millones, ed., Las informaciones, $1 / 17$.

34/ Molina (1574), Relación de las fábulas, 80 (el énfasis es mío). Ver también Millones, ed., Las informaciones, $1 / 17-1 / 18$.

35/ Un contraste sugerente en términos similares, entre colonizadores y amos de esclavos, se encuentra en Eugene D. Genovese, Roll, Jordan, Roll: The World the Slaves Made (New York, 1974), 91.

36/ Ver John Earls, "La organización del poder en la mitología quechua". en Ossio, ed., Ideología mesiánica, 395-414.

$37 /$ Millones, ed., Las informaciones, $1 / 22$.

38/ Ibid., 2/136.

$39 /$ Sobre esta clase de visión como una utopía de la élite nativa, consultar Emilio Choy, "La realidad y'el utopismo en Guamán Poma", Univer. sidad, n. 7(Ayacucho, diciembre 1966), 1-2.

40/ Información sugerente sobre el diferente uso del término "yanacona" en el centro minero de Potosí se encuentra en Marie Helmer, "Notas sobre la encomienda peruana en el siglo XVI", Revista del Instituto de Historia del Derecho, 10 (Buenos Aires, 1959), 124-43.

$41 /$ Sobre el atractivo perenne del ambiente comunal aun para los miembros más apartados $y$. marginalizados de las comunidades campesinas de los Andes, ver Enrique López Albújar, "Ushanam-Jampi", en Cuentos andinos (Lima, 1920), 43-50. esp. 49-50. Una información interesante sobre intentos en los Andes para recrear relaciones comunales con los colonizadores mitmay que se hallaban en lugares distantes a la zona "nuclear" de asentamiento, nos la proporciona Albornoz (c. 1582), "Instrucción para descubrir", 21. Si se desea consultar material comparativo sobre el vacío espiritual experimentado por los vietnamitas que habían sido obligados a dejar sus ambientes colectivos de vida comunal, y su susceptibilidad hacia los cultos religiosos, ver Fitzgerald, Fire in the Lake, 79, 239.

42/ Se encuentran ejemplos en Millones, ed., Las informaciones, $2 / 70$, $2 / 44$.

$43 /$ Ibid., 2/68, 4/15-4/16, 4/23, 4/34/5, 4/17-4/18; ver también Albornoz (c. 1582), "Instrucción para descubrir", 38.

44/ Ver Millones, ed., Las informaciones, 2/26, 2/36, 2/78, 2/89, 2j95. $2 / 104,2 / 110,1 / 22,3 / 29$.

45/ La "Relación de Amancebados" (1584) contiene listas útiles pero incompletas de Soras y Lucanas. Ver Millones, ed., Las informaciones, $4 / 6-4 / 11,4 / 18-4 / 22,4 / 41-4 / 42$, $4 / 34-4 / 36,4 / 31-4 / 32$, en lo cual se basa el análisis siguiente.

46/ Millones, ed., Las informaciones, $4 / 8$.

47/ Ibid., 1/22.

48/ Algunas contradicciones definidas, sin embargo, son las que proporcionan Francisco Chuqui Vilca, don Antonio Guamán Lauca, don Pedro Caxa y Tomás Vásquez Tomay, en Ibid., 4/34-4/36.

49) La información para Lucanas Laramati se encuentra en Ibid., 4/31$4 / 39$.

$50 /$ Ibid., 2/68, 2/64. 
$51 /$ Consultar las relaciones sobre los pobladores de Soras y Lucanas en Ibid., 4/16, 4/27-4/28, 4/38-4/39.

52/ Esta distinción no excluye la posibilidad que dirigentes importantes de la secta hayan sido jefes menores o parientes cercanos de los principales kurakas. Sobre conflictos y divisiones intraélites en la vida andina, ver María Rostworowski de Diez Canseco, Curacas y sucesiones, costa norte (Lima, 1961) y "Succession, Coöption to Kinship, and Royal Incest Among the Incas", en Southwestern Journal of Anthro. pology, 16 (Invierno 1960), 417 27; BNP, A371, 1594.

Un cjemplo comparativo sobre élites menores como fuentes de desasosiego en una sociedad basada en cl linaje, se encuentra en E.R. Lcach, Political Systems of Highland Burma (Boston: Beacon ed., 1965), 197-263.

53/ Millones, ed., Las informaciones, $2 / 118$.

54/ Ver Albornoz (c. 1582), "Instrucción para descubrir", 22, 36.

55\% Cf. Frantz Fanon, The Wretched of the Earth, trad. Constance Farrington (New York, 1968), 52-54.

56/ Ver RPIA, tomo 5, partida VI, 19. 20 ; tomo 8, partida XL, 132 ; tomo 10, partida CXXIII, 404-5; tomo 10, partida CXL, 468-69; tomo 14, partida VI, 42-43.

57/ "Relación de Amancebados" (1584), en Millones, ed., Las infor. maciones, 4/44-4/45.

58/ Millones, ed., Las informaciones, 2/ $69,2 / 112,2 / 90,2 / 96,2 / 22,2 / 27$. $2 / 33,2 / 37,2 / 54-2 / 55,2 / 47,4 / 33$.

$59 /$ Ibid., 2/62, 2/46.

60/ La caracterización anterior es una interpretación que se basa en vastas lecturas de la extensa literatura que existe sobre el milenarismo. Algunos estudios clásicos son los de Kenelm Burridge, New Haven, New
Earth: A Study of Millenarian Activities (New York, 1969); Norman Cohn, The Pursuit of the Millennium: Revolutionary Millenarians and Mystical Anarchists of the Middle Ages (3ra. ed., New York, 1970); E.J. Hobsbawm, Primitive Rebels: Studies in Archaic Forms of Social Movements in the 19th and 20 th Centuries (New York, 1965); María Isaura Pereira de Queiroz, Historia y etnología de los movimientos mesiánicos, trad. Florentino M. Torner (México, 1969); Anthony F.C. Wallace, "Revitalization Movements". A merican Anthropologist, 58 (Abril 1956). 264-81; Wallace, The Death and Rebirth of the Sencca (New York, 1969); Worsley, The Trumpet.

No he querido decir que todos los movimientos milenaristas impliquen una incapacidad para lanzar un ataque humano político-militar contra los opresores. Un enfoque de esa índole scrla estrecho y rígido y estaría dejando de lado aquellos casos en donde las ideologías milenarias sin duda han llegado a inspirar asaltos militares contra los poderes ahí presentes.

61/ Ejemplos de estos dos enfoques importantes sobre el milenarismo se encuentran en la nota 60 . Wachtel, "Rebeliones y milenarismo", hace una interpretación del Taki Onqoy dentro del contexto de "desestructuración". Críticas a ambos enfoques se encuentran en Sylvia Thrupp, "Millennial Dreams in Action", en Thrupp, ed., Millennial Dreams in Action: Studies in Re. volutionary Religious Movements (New York, 1970), 26-27.

62/ Sobre los neoincas, consultar George Kubler, "The Neo-Incas State (1537-1572)", HAHR, 27 (mayo 1947), 189-203; Kubler, "The Quechua in the Colonial World". 
en Julian H. Steward, ed., Hand. book of South American Indians (7 vols., Washington, D.C., 194659), II, 343-45; John Hemming, The Conquest of The Incas (New York, 1970), passim.

63/ En relación a la historia de los huancas y su postura después de la conquista, ver Waldemar Espinoza Soriano, La destrucción del imperio de los Incas (Lima 1973); y sobre su conspiración en la década de 1560, consultar Manuel de Odriozola, Documentos históricos del Perí (Lima, 1872), III, 3-9; Wachtel, "Rebeliones y milenarismo", 113-15.

64/ Wachtel, "Rebeliones y milenarismo", 119. Ver también las sospechas de Albornoz en el sentido de que los neoincas instigaron el Taki Onqoy para desatar una rebelión: Albornoz (c. 1582), "Instrucción para descubrir", 35-37.

65/ Molina (1574), Relación de las fábulas, 82.

66) Sobre la crisis de la década de 1560 , y sobre la información anterior, consultar Guillermo Lohmann Villena, "Juan de Matienzo, autor del 'Gobierno del Perú' (su personalidad y su obra), Anuario de Estu. dios Americanos, 22 (Sevilla, 1965), 767-886; John H. Rowe, "The Incas Under Spanish Colonial Institutions", $H A H R, 37$ (mayo, 1957), 184, 171; Guillermo Lohmann Villena, El corregidor de los indios en el Perú bajo los Austrias (Ma drid, 1957), nota sobre 28; Barnadas, Charcas, 283; Patricia J. Bard, "Domingo de Santo Tomás: A Spanish Friar in Sixteenth Century Peru" (tesis de M.A., Columbia University, 1967), 61; Hemming, Conquest, 304-7; Albornoz (c. 1582), "Instrucción para descubrir", 36.
67/ Ver Lohmann, “Juan de Matienzo", 767-886.

68/ Emilio Lissón Chavez, ed., La igle. sia en el Perú (4 vols., Sevilla, 194346), II, 294. 